\title{
Fossilized Jews and Witnessing Dinosaurs at the Creation Museum: Public Remembering and Forgetting at a Young Earth Creationist "Memory Place"
}

\author{
DUSTIN NASH \\ dustinnash@muhlenberg.edu \\ Muhlenberg College, Allentown, PA 18104
}

\section{Introduction $^{1}$}

Since opening in May 2007 in Petersburg, Kentucky, the Creation Museum has defined itself as a "\$27 million, high-tech masterpiece." The facility is the brainchild of Ken Ham, co-founder and president of the Christian apologetics ministry Answers in Genesis (or AiG). As such, it represents his decades-long desire to erect a museum that would challenge a secular, evolutionary description of our planet's natural history. ${ }^{3}$ In its place, the Creation Museum argues that science, when properly understood, aligns with the biblical account of God's creation of the cosmos. This claim stands at the heart of Young Earth Creationism: a particular religio-scientific ideology and counter-cultural movement that claims God created the Earth and all life upon it a little less than 6,000 years ago. ${ }^{4}$

\footnotetext{
${ }^{1}$ Examination of the Creation Museum by my students in the course "Proving the Unprovable: Religion, Science, and the 'Unknown' in Modernity" from 2016-2017 greatly advanced the research that supports the present study. I wish to cite them by name in thanks for their insights and probing questions: Lauren Brinkman, Michael Colasurdo, Faryd Daza, Colin Deitch, Steven Di Preta, Michael Dougan, Nathan Emrick, Brianna Ennis, Ariana Feliziani, Evan Giannetti, Devin Goldsmith, Daniel Hanna, Jared Hildreth, Sarah Hunter, Benjamin Katz, Emily Lax, Stephen Lederkramer, Jocelyn Lengen, Alexander Mack, Maxwell Marcus, Ari Matlick, Delsin Mayne, Arianna Mesrobian, Christian Nazare, Patrick Palmer, Raquel Rotem, Brent Siegel, Benjamin Solomon, Jon Stoerrle, and Liana Zaino.

2 "Creation Museum Fact Sheet," Creation Museum Media Kit, accessed April 4, 2018. https://creationmuseum.org/press/\#.

${ }^{3}$ Ken Ham, introduction to Journey Through the Creation Museum (Green Forest, AR: Master Books, 2016), 7.

${ }^{4}$ Howard J. van Till, "Creationism," in Encyclopedia of Science and Religion, ed. J. Wentzel Vrede van Huyssteen, vol. 1 (New York: Macmillan Reference, 2003), 187-190. doi: 10.1163/22112685 eco C1462. On the Creation Museum as a site of cultural reproduction, see Lindsay Marie Barone, "The New Pulpit: Museums, Authority, and the Cultural Reproduction of Young-Earth Creationism" (PhD diss., University of Wisconsin-Milwaukee, 2015), 1-88. The Young Earth Creationist ideology of the museum draws heavily on the enterprise of "creation science," which can be traced to the work of Morris and Moore in the 1960s and 1970s. Ronald L. Numbers, The Creation-
} 
The present study will show that, beyond its missionary agenda, the Creation Museum represents a potent memory place that provides institutional legitimacy to a Young Earth interpretation of the past. Furthermore, examination of the memory that the facility constructs reveals a notable silence with regard to Jews and Jewishness. This quiet is all the more significant in light of the museum's structural allusions to the theological system of Dispensationalism, as well as the broader interest that Christian communities have held regarding the place of Jews in the divine plan for history since antiquity. In contrast to the absence of Jews, representations of dinosaurs pervade the site. Close analysis reveals that AiG's rhetorical emphasis on these terrible lizards within its totalizing narrative of time has created a surprising discursive connection between the site's representation of Jews and dinosaurs. Put simply, the Jewish people come to embody fossils of a bygone age at the Creation Museum, rather than the expected ancient reptiles. ${ }^{5}$

\section{"The Evidence is in the Present...But What Happened in the Past",}

The precise number of museums or attractions within the United States devoted to Creationism is difficult to ascertain. As Linville notes on his website "Contemporary Creationism," this is due to the fact that they are often small in scale with frequent openings and closures. ${ }^{7}$ Nevertheless, Bielo's digital catalogue lists roughly thirty seven facilities of this type, with the first installations dating to the $1970 \mathrm{~s}^{8}$ AiG's Creation Museum stands out as the largest and most well-funded of these sites built to date. ${ }^{9}$ Moreover, the museum's website claims

ists: From Scientific Creationism to Intelligent Design (Cambridge: Harvard University Press, 2006), 268-285.

${ }^{5}$ The museum's depiction of Jews as "fossils" echoes the British historian Arnold J. Toynbee's controversial assessment of Judaism's continued presence in the world in his A Study of History, the first three volumes of which were initially published in 1934. For more on his claim that Jews constitute "fossils" of a distinct "Syriac Society" see Arnold J. Toynbee, A Study of History, vol. 2 (London: Oxford University Press, 1945), 234-248.

${ }^{6}$ Placard Text, "The Evidence is in the Present...But What Happened in the Past," Dig Site, Creation Museum, Petersburg, KY.

7 "Creation Museums, Field Trips, \& Zoos," Contemporary Creationism, accessed April 2, 2018, http://contemporarycreationism.com/creation-museums/. This website represents a digital resource that accompanies Linville's research project "The Creation of Myth and Meaning in Young Earth Creationism." For an additional list of such sites from an anthropological perspective, see https://www.materializingthebible.com/. "Materializing the Bible" represents a digital scholarship project directed by Bielo of Miami University on Bible-based attractions throughout the world.

"Creation Museums," Materializing the Bible, accessed April 2, 2018, https://www.materializingthebible.com/creation-museums.html. This total does not incorporate museums dedicated to the Bible without assertion of a form of creationism. The Museum of the Bible in Washington, D.C. represents such a space. For more on this site, see Candida R. Moss and Joel S. Baden, Bible Nation: The United States of Hobby Lobby (Princeton: Princeton University Press, 2017). Alternatively, Barone counts thirty four Creation Museums in their 2015 study. Barone, "The New Pulpit," 7. Regarding the ever-changing nature of this count, note that the Institute for Creation Research plans to open a newly constructed "Discovery Center" in Dallas, Texas in 2019. "ICR Discovery Center," accessed April 2, 2018, http://www.icr.org/discoverycenter.

${ }^{9}$ On the associated attraction Ark Encounter, which opened in the summer of 2016, see James S. Bielo, Ark Encounter: The Making of a Creationist Theme Park (New York: NYU Press, 2018). 
that more than 3.5 million people have visited the facility since its opening a little over a decade ago. This number, along with the construction of new exhibits and the initiation of annual Spanish language tours, bears witness to the museum's growing popularity and cultural significance in the United States. ${ }^{10}$

This status would seem to rest on the experience that visitors enjoy at the site, especially in its main exhibit, the Walk Through History. Displays within this section of the museum span more than twenty named rooms accessed by strictly guided movement. Each room presents a sub-claim that supports the Creation Museum's larger thesis, and therefore must be consumed by patrons in order. This embodied argument begins in the initial rooms of the exhibit by raising epistemic questions about the material evidence of an ancient Earth, while also stressing the historical reliability of the Christian Bible: "The Evidence is in the Present...But What Happened in the Past?"11 Butler has cogently shown that such rhetorical questions, and the doubt that they imply regarding mainstream scientific conclusions, is a fundamental component of the museum's rhetoric. Thus, in their present context such statements simultaneously seek to elevate a "social constructionist critique of scientific knowledge" while also asserting "biblical inerrancy as "fact.", 12

The Walk Through History then shifts to discuss the ways in which contemporary societies have pushed a biblical worldview from mainstream culture. This claim is made manifest by the physical representation of a wrecking ball with the words "Millions of Years" sitting in the rubble of a collapsing church, whose windows play videos depicting the pastor's family engaging in drug use, watching pornography, and contemplating abortion (figure 1).

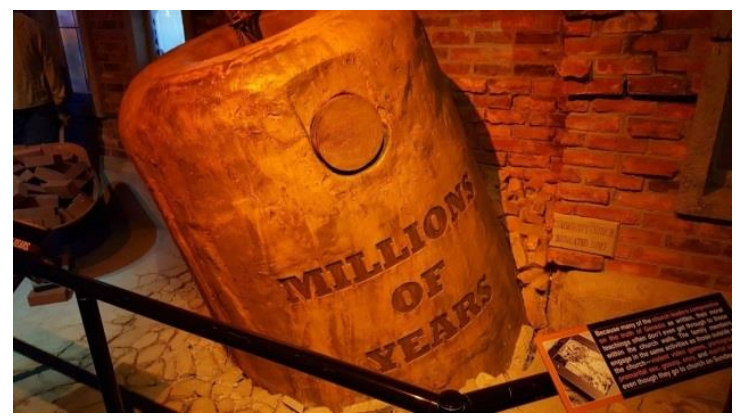

Figure 1. The "Millions of Years" wrecking ball destroys a Christian church in the Culture in Crisis room. Photograph by Dustin Nash.

\footnotetext{
10 "Record Crowds as Creation Museum Celebrates $10^{\text {th }}$ Anniversary: Two New Large Exhibits to Open by Memorial Day Weekend," last modified May 26, 2017, https://answersingenesis.org/about/press/2017/05/26/record-crowds-creation-museum-celebrates10th-anniversaryl. "Ark Encounter and Creation Museum to Host Día Latino For Spanish-Speaking Guests," accessed November 13, 2018, https://creationmuseum.org/press/ark-encounter-and-creationmuseum-host-d\%C3\%ADa-latino-spanish-speaking-guests/.

${ }^{11}$ Placard Text, "The Evidence is in the Present...But What Happened in the Past," Dig Site, Creation Museum, Petersburg, KY.

${ }^{12}$ Ella Butler, "God is in the Data: Epistemologies of Knowledge at the Creation Museum," Ethnos 75, no. 3 (2010): 234. doi: 10.1080/00141844.2010.507907.
} 
It is only after passing through this emotionally loaded environment that visitors move back thousands of years through the Time Tunnel from the present day to the moment of creation. An ever-repeating film dramatizes this event in the Six Days Theater, complete with computer generated affects and an epic, symphonic score.

The structure of the main exhibit changes at this stage in accordance with the notion of an eternal divine plan, organizing the remaining rooms to fit a schematized vision of history divided by particular events. The facility entitles these temporal fault lines "the 7 Cs." 13 Displays dedicated to the first four Cs (Creation, Corruption, Catastrophe, and Confusion) follow, portraying the stories of Adam and Eve, Cain and Abel, Noah's flood, and the Tower of Babel (figure 2).
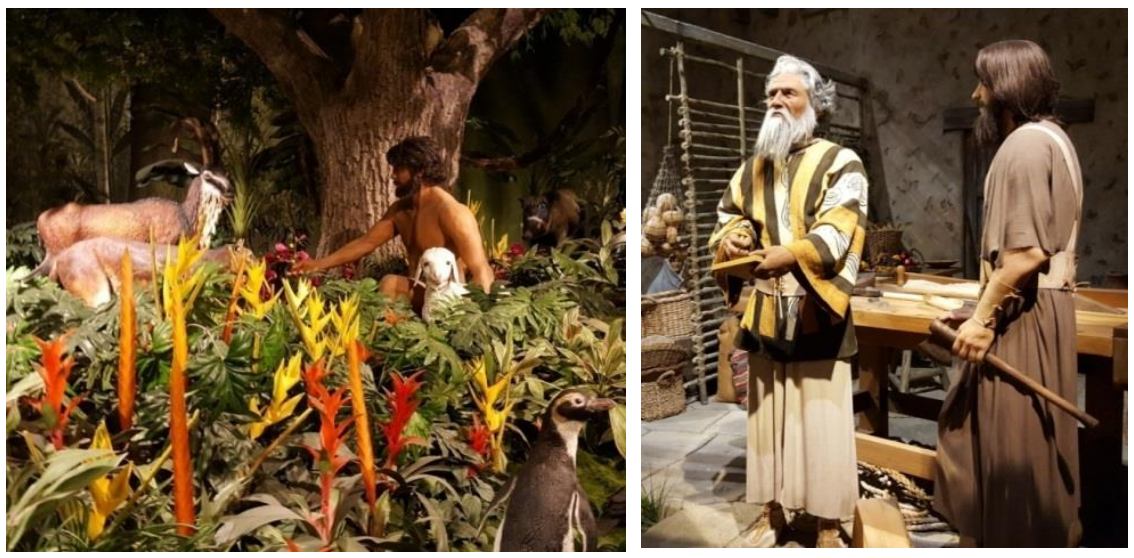

Figure 2. Adam names the animals and meets Eve for the first time in the Creation-Garden of Eden Room, while Noah supervises workers in the Catastrophe-Ark Construction Room. Photographs by Dustin Nash.

The final three Cs (Christ, Cross, and Consummation) formed only a cascade of placards outside the main exhibit's final room during my initial fieldwork at the site. However, this is no longer the case. The Creation Museum opened new exhibits dedicated to these Cs on Memorial Day 2017. ${ }^{14}$ Featuring original artwork, these rooms dramatically portray the life, death, and future return of Jesus.

The exhibits described above have elicited significant scholarly interest. In its most popular forms, much of that focus has centered on scientific critiques of the museum's claims regarding evolution. Bill Nye's public debate with Ken Ham in 2014 at the Creation Museum and "The Science Guy's" resulting popular book Undeniable: Evolution and the Science of Creation exemplify this confrontational approach. ${ }^{15}$ However, other researchers have sought to understand the

\footnotetext{
${ }_{13}^{13}$ Journey, 10.

14 "New Exhibit Opening Memorial Day Weekend," Creation Museum, last modified May 25, 2017, https://creationmuseum.org/blog/2017/05/25/new-exhibit-opening-memorial-day-weekend/.

${ }_{15}$ Bill Nye, Undeniable: Evolution and the Science of Creation (New York: St. Martin's Griffin, 2015).
} 
museum from the standpoint of its cultural function and rhetorical strategies. ${ }^{16}$ The present study continues this line of investigation by questioning the Creation Museum's relationship to public memory.

\section{The Creation Museum as Memory Place}

The subject of public memory offers a productive lens for examining the Creation Museum, due to its outward form and rhetorical goals. In place of the static and unified notion of the past that the term history elicits, researchers in a variety of disciplines have turned to memory as a way to understand the "multiple, diverse, mutable, and competing accounts of past events" that can take shape between (or within) particular social, cultural, or historical collectivities. ${ }^{17}$ Indeed, scholars are now in agreement that while individual cognitive processes play a role in memory, the act of remembering "takes place in groups." 18 The modifier public in public memory designates the rhetorical positioning of group memories within those contexts for which they will do the most work for a particular collective. ${ }^{19}$ Public memory is also notable for the way in which contemporary concerns activate it, as groups selectively mobilize a past in order to make meaning out of the present. ${ }^{20}$ In this way, public memories construct shared narratives that maintain the boundaries of collective identities. ${ }^{21}$

\footnotetext{
${ }^{16}$ For example, see Stephen T. Asma, "Risen Apes and Fallen Angels: The New Museology of Human Origins," Curator 54, no. 2 (2011): 141-163. doi: 10.1111/j.2151-6952.2011.00078.x; Barone, "New Pulpit"; Butler, "God is in the Data," 229-251; Julie Anne Duncan, "Faith Displayed as Science: The Role of the 'Creation Museum' in the Modern American Creationist Movement" (master's thesis, Harvard University, 2009). doi: 10.2139/ssrn.2007942; Casey Ryan Kelly and Kristen E. Hoerl, "Genesis in Hyperreality: Legitimizing Disingenuous Controversy at the Creation Museum," Argumentation and Advocacy 48 (2012): 123-141. doi: 10.1080/00028533.2012.11821759; Linville, "The Creationist MOTB"; John Lynch, "Prepare to Believe': The Creation Museum as Embodied Conversion Narrative," Rhetoric \& Public Affairs 16, no. 1 (2013): 1-27. doi: 10.14321/rhetpublaffa.16.1.0001; David W. Scott, "Dinosaurs on Noah's Ark? Multi-Media Narratives and Natural Science Museum Discourse at the Creation Museum in Kentucky," Journal of Media and Religion 13 (2014): 226-243. doi: 10.1080/15348423.2014.971570; Jeffrey Steller, "The Creationist Tales: Understanding a Postmodern Museum Pilgrimage," in The Changing World Religion Map, eds. Stanley D. Brunn and Donna A. Gilbreath, 5 vols. (Dordrecht: Springer, 2015), 25412561. doi: 10.1007/978-94-017-9376-6_133; Susan L. Trollinger and William Vance Trollinger, Jr., Righting America at the Creation Museum (Baltimore: Johns Hopkins University Press, 2016).

${ }^{17}$ Kendall R. Phillips, introduction to Framing Public Memory, ed. Kendall R. Phillips (Tuscaloosa: The University of Alabama Press, 2004), 2. The notion that history and memory comprise completely separate activities is, nevertheless, contested. See Marita Sturken, Tangled Memories: The Vietnam War, the AIDS Epidemic, and the Politics of Remembering (Berkeley: University of California Press, 1997), 3-6.

${ }^{18}$ Carole Blair, Greg Dickinson, and Brian L. Ott, "Introduction: Rhetoric/Memory/Place," in Places of Public Memory: The Rhetoric of Museums and Memorials, eds. Greg Dickinson, Carole Blair, and Brian L. Ott (Tuscaloosa: The University of Alabama Press, 2010), 5-6. See also Maurice Halbwachs, On Collective Memory, ed. and trans. Lewis A. Coser (Chicago: University of Chicago Press, 1992), 43.

${ }^{19}$ Blair, Dickinson, and Ott, "Introduction," 6.

${ }^{20}$ Blair, Dickinson, and Ott, "Introduction," 6-9; Alan J. Lambert, Laura Nesse Scherer, Chad Rogers, and Larry Jacoby, "How Does Collective Memory Create a Sense of the Collective," in Memory in Mind and Culture, eds. Pascal Boyer and James V. Wertsch (Cambridge: Cambridge University
} 
The social nature of public memory also links this idea in an intimate fashion to the concept of place, as differentiated spaces are needed in order to structure and communicate shared memories beyond the level of the individual. First popularized in Nora's Les Lieux de Mémoire, continued research has shown that museums, preservation sites, battlefields, and memorials function as especially potent "memory places." 22 In fact, survey data reveals that Americans regard museums as particularly authoritative sources on the past. ${ }^{23}$ In their role as memory places, therefore, museums of all kinds function to provide a sense of authenticity to the memories that groups maintain, and define the boundaries of identities tied to those memories. ${ }^{24}$ They accomplish this feat by proposing "a specific kind of relationship between past and present that may offer a sense of sustained and sustaining communal identification." 25 The visitor, as a result, comes to view the present and its meaning as connected in a knowable way to a "significant past."26 Museums wield considerable political power to shape this memory of the past by selecting, displaying, and guiding the patron's sensory experience of it. $^{27}$

As the previous section's description of the Creation Museum shows, the site fits the criteria of a memory place on each account. First, Trollinger and Trollinger have compellingly analyzed the ways in which the museum's vision of the past is a product of the designers' understanding of contemporary American culture, especially in the way that it makes the present knowable as a product of Christian moral decline. ${ }^{28}$ An emotional overtone is an unambiguous element of this message's rhetoric, with the museum associating Young Earth Creationism

Press, 2009), 195-196; Paul Ricoeur, "From 'Memory - History - Forgetting," in The Collective Memory Reader, eds. Jeffrey K. Olick, Vered Vinitzky-Seroussi, and Daniel Levy (Oxford: Oxford University Press, 2011), 478; Sturken, Tangled Memories, 1.

${ }^{21}$ Jan Assmann, Moses the Egyptian: The Memory of Egypt in Western Monotheism (Cambridge: Harvard University Press, 1997), 14-15; Jan Assmann and John Czaplicka, "Collective Memory and Cultural Identity," New German Critique 65 (1995): 130. doi: 10.2307/488538; Robert Bellah et al., "From Habits of the Heart: Individualism and Commitment in American Life" in The Collective Memory Reader, eds. Jeffrey K. Olick, Vered Vinitzky-Seroussi, and Daniel Levy (Oxford: Oxford University Press, 2011), 229-230; Blair, Dickinson, and Ott, "Introduction," 9; Halbwachs, Collective Memory, 46; Lambert et al., "Sense of the Collective," 194-195; Sturken, Tangled Memories, 1.

${ }^{22}$ Pierre Nora, "From Lieux de mémoire to Realms of Memory", in Realms of Memory: Rethinking the French Past, vol. 1, ed. Pierre Nora (New York: Columbia University Press, 1996), xvii; Blair, Dickinson, and Ott, "Introduction," 24; James E. Young, The Texture of Memory: Holocaust Memorials and Meaning (New Haven: Yale University Press, 1993), 6-7.

${ }^{23}$ Roy Rosenzwerig and David P. Thelen, The Presence of the Past: Popular Uses of History in American Life (New York: Columbia University Press, 1998), 105-108; Scott, "Dinosaurs on Noah's Ark," 228.

${ }^{24}$ Elizabeth Crooke, Museums and Community: Ideas, Issues and Challenges (New York: Routledge, 2007), 129; Margaret M. Gold, "Windows on the Eternal: Spirituality, Heritage and Interpretation in Faith Museums," in The Changing World Religion Map, eds. Stanley D. Brunn and Donna A. Gilbreath, 5 vols. (Dordrecht: Springer, 2015), 2537. doi: 10.1007/978-94-017-9376-6_132.

${ }^{25}$ Blair, Dickinson, and Ott, "Introduction," 27.

${ }^{26}$ Blair, Dickinson, and Ott, "Introduction," 27.

${ }^{27}$ Blair, Dickinson, and Ott, "Introduction," 25-30. On the similarly partisan character of memorial monuments, see Young, Texture of Memory, 15.

${ }^{28}$ Trollinger and Trollinger, Righting America, 36-63. 
with notions of divine love, scientific rigor, and the comfort of a purposeful life. At the same time, numerous exhibits imply a connection between the theory of evolution and moral relativism (figure 3$)^{29}$

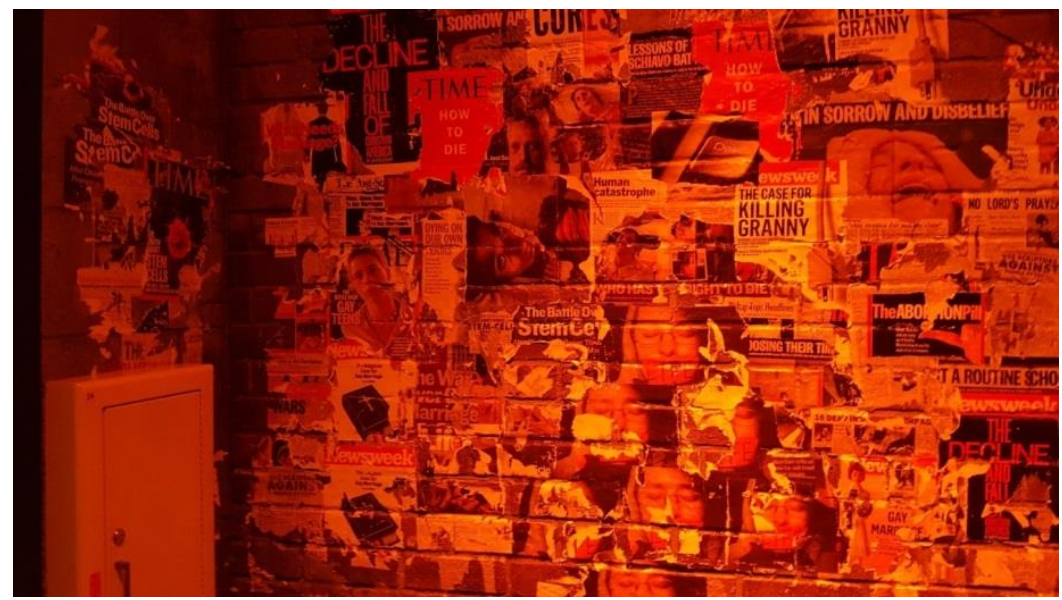

Figure 3. The entry to the Culture in Crisis room evokes the feeling of a threatening urban alleyway, including low lighting and magazine covers plastered on a faux brick wall. References appear among the collage of images to euthanasia, "the abortion pill," "gay marriage," and prayer in school. Following displays and placards explain that these negatively perceived issues are a byproduct of mainline Christian leaders abandoning belief in the Bible's historical accuracy. Photograph by Dustin Nash.

Second, the facility rhetorically communicates that message through organized walking and the selective display of objects in a form that embodies the classic natural history museum experience. ${ }^{30}$ Therefore, although the Creation Museum's lack of an accessioned collection prevents it from meeting the standards for accreditation by the American Alliance of Museums, its outward form allows it to participate in the authority that contemporary American society attaches to these memory places. ${ }^{31}$ The extent to which designers have done this in order to intentionally oppose prevailing secular scientific views on cosmology and evolution highlights the facility's place within an emerging global phenomenon of "tactical museology." This term refers to a process by which certain groups around the world today are invoking, and thereby challenging, the authority of the museum

\footnotetext{
${ }^{29}$ Asma, "Risen Apes," 146-148; Kelly and Hoerl, "Genesis in Hyperreality," 132.

${ }^{30}$ Scott, "Dinosaurs on Noah's Ark," 234; Trollinger and Trollinger, Righting America, 16-25. For more on the preformative elements of this experience, see Jill Stevens, "Embodying Sacred History: Performing Creationism for Believers," The Drama Review 56, no. 1 (2012): 99-104.

${ }^{31}$ Asma, "Risen Apes," 146; Kelly and Hoerl, "Genesis in Hyperreality," 125. On eligibility for the American Alliance of Museums, see "Eligibility Criteria," American Alliance of Museums, accessed April 12, 2018, http://www.aam-us.org/resources/assessment-programs/accreditation/eligibility. On whether or not this is disingenuous appropriation, see Kelly and Hoerl, "Genesis in Hyperreality," 138-140. Cf. Trolliinger and Trollinger, Righting America, 60-63.
} 
idea in order to counter official narratives that their societies' established institutions tell. ${ }^{32}$

Thus, it is clear that while official AiG statements define the Creation Museum's audience as global and its purpose as missionary, the site functions above all as a powerful memory place for the American Young Earth Creationist community. In this role it provides institutional authenticity to interpretations of the past and present that legitimate a Young Earth Creationist identity by allowing members of the group to collectively remember a shared biblical past as an element of their own group's history. ${ }^{33}$ In other words, this is a space that confirms an already established identity; it does not change it. The museum's situated character as a place supports this interpretation of its function, for as Crooke notes people are unlikely to visit such an institution "unless they consider themselves members of the communities the exhibitions represent. Non-members would not have the cultural knowledge to interpret the collections or the social experience to feel at ease in the spaces where the exhibitions were held." 34 Engaging in the planning necessary to visit a memory place, as well as the cost to do so, represent additional factors that make visiting a site such as the Creation Museum an intentional act. $^{35}$

A 2014 Gallop Poll found that more than four in ten Americans affirmed the statement "God created human beings pretty much in their present form at one time within the last 10,000 years." appeal of an institution that legitimates a Young Earth memory of the past. Yet, it is also important to note that the way in which the Creation Museum links its particular scientific and historical arguments to contemporary social issues suggests that its functional horizon as a memory place may extend well beyond those who actively assert such a position on the planet's age. Indeed, it frames its antievolutionist claims within a much broader framework of the "persistent moral disputes, commonly referred to as culture wars." 37 As Trollinger and Trollinger summarize, the museum's displays and associated AiG media "speak on any and all topics of the day: the status of the United States as a Christian nation, gay marriage, the role of women, racism, climate change, public education," and more. ${ }^{38}$ The Creation Museum, moreover, depicts the debate surrounding these issues as a monolithic binary, and its own position as morally righteous. ${ }^{39}$ However, despite the fact that the public continues to view the culture wars in the United States as the opposition of two comprehensive worldviews, sociologists and others have

\footnotetext{
32 Gustavo Buntinx and Ivan Karp, "Tactical Museologies," in Museum Frictions: Public Cultures/Global Transformations, eds. Ivan Karp et al. (Durham: Duke University Press, 2006), 207-218.

${ }^{33}$ Barone, "New Pulpit," 22; Stevenson, "Embodying Sacred History," 94-96.

${ }^{34}$ Crooke, Museums and Community, 129.

${ }^{35}$ Blair, Dickinson, and Ott, "Introduction," 26.

${ }^{36}$ Frank Newport, "In U.S., 42\% Believe Creationist View of Human Origins," accessed April 17, 2018, http://news.gallup.com/poll/170822/believe-creationist-view-human-origins.aspx.

${ }^{37}$ Eric Orion Silva, "Neutralizing Problematic Frames in the Culture Wars: Anti-Evolutionists Grapple with Religion,” Symbolic Interaction 37, no. 2 (2014): 226.

${ }^{38}$ Trollinger and Trollinger, Righting America, 149.

${ }^{39}$ Trollinger and Trollinger, Righting America, 149.
} 
recently noted that the boundaries between the two camp's culture warriors are in reality "neither static nor uniform." 40 Analysts have therefore begun to focus more strongly on the work that is done to structure and perpetuate these conflicts, viewing the battle lines as cultural products in-and-of themselves. ${ }^{41}$ Consequently, despite its "totalizing rhetoric," the Creation Museum can foster support from individuals that may otherwise be agnostic to its historical claims by associating them with more widely held conservative "social values, norms, and beliefs."

One significant sub-set of this broader "memory audience" may be American Evangelical Christians. The lack of a single institutional framework or shared creedal statement, however, has made Evangelicals a notoriously difficult population to define. As a particular religious tradition within the larger web of contemporary protestant Christian communities, Bebbington has provided a useful summary of four characteristics that have marked "Evangelicalism" since the $18^{\text {th }}$ century. These include "conversionism, the belief that lives need to be changed; activism, the expression of the gospel in effort; biblicism, a particular regard for the Bible; and what may be called crucicentrism, a stress on the sacrifice of Christ on the cross." ${ }^{43}$ An individual's relationship to these ideas, to say nothing of their multiform interpretation, may vary widely. Nonetheless, the Creation Museum clearly emphasizes each of these four characteristics. First, Lynch has thoroughly demonstrated the way in which the Creation Museum's main exhibits, and the forced linearity of the rooms' connected discourse, "hews closely to the Protestant conversion narrative." ${ }^{\prime 4}$ As for activism, the facility's mission statement makes its interest in spreading the gospel explicit when it asserts that one of the museum's goals is to "equip Christians to better evangelize the lost through a combination of exhibits, research, and educational presentations that uphold the inerrancy of the Bible." ${ }^{45}$ This statement also reflects the museum's biblicism, which manifests in the ultimate authority that it gives to the Bible concerning knowledge of the past. Finally, the expanded exhibits dedicated to the final three Cs (Christ, Cross, and Consummation) bear witness to the site's crucicentrism. With these conjunctions of interest in mind, and the composite and contingent nature of identities related to social movements, it becomes quite clear that there are a sizeable number of American citizens and others for whom the

\footnotetext{
${ }^{40}$ James Davison Hunter, Culture Wars: The Struggle to Define America (New York: BasicBooks, 1991), 42-43; Silva, "Neutralizing," 228.

${ }^{41}$ Michael Ian Borer and Adam Murphree, "Framing Catholicism: Jack Chick's Anti-Catholic Cartoons and the Flexible Boundaries of the Culture Wars," Religion and American Culture 18, no. 1 (2008): 110, no.13.

${ }^{42}$ Trollinger and Trollinger, Righting America, 149; Shoon Lio, Scott Melzer, and Ellen Reese, "Constructing Threat and Appropriating 'Civil Rights': Rhetorical Strategies of Gun Rights and English Only Leaders," Symbolic Interaction 31, no. 1 (2008): 8.

${ }^{43}$ David W. Bebbington, Evangelicalism in Modern Britain: A History from the 1730 s to the $1980 \mathrm{~s}$ (London: Routledge, 1988), 16. See also the summary of Bebbington's characteristics in Mark A. Noll, American Evangelical Christianity: An Introduction (Oxford: Blackwell Publishers, 2001), 13.

${ }^{44}$ Lynch, "Prepare to Believe," 16.

45 "Creation Museum Main Theme and Mission Statement," Creation Museum Media Kit, accessed May 5, 2016. https://creationmuseum.org/press/.
} 
Creation Museum is well situated to institutionally validate components of their existing identity as a memory place.

With this inner-communal function and broader audience in mind, it is necessary to point out that, as Olick writes, "memory-makers don't always succeed in creating the images they want and in having them understood in the ways they intended." ${ }^{46}$ The selective enterprise of museum display is not semantically univocal. Both unintentional and strategic choices made in this process can have significant, rhetorical implications. Therefore, an analysis of the memory that the Creation Museum constructs, outside of the official narrative that AiG presents regarding it, is necessary. To that end, consideration of what the museum chooses to forget or remember reveals a connection between the representation of Jews and dinosaurs.

\section{Forgetting Jews as Part of the Christian Past}

In a facility dedicated to the Bible and history, the absence of Jews from the Creation Museum's memory of the Christian past is immediately noticeable. Nevertheless, this silence is not wholly unexpected. The museum is, after all, an explicitly Christian institution. Visitors would be justified in the expectation that the museum will limit textual or visual representations of Jews and Jewishness to those instances in which they serve the needs of the larger Christian narrative. Yet, the empty spaces created by the absence of Jews leaves definable shapes. The result is a clear message regarding the irrelevance of Judaism for the museum's memory of the Christian past. Furthermore, in those few cases in which references to Jewishness do occur, the representation aligns with the message that the overarching silence communicates. To put it simply, Jews constitute peculiar, but nevertheless ossified remnants of an ancient past that serve no theological function within the public memory that the Creation Museum constructs.

The systematic avoidance of Jews at the museum is noteworthy due to the interest that Christian communities have traditionally held with regard to that people's place within the divine plan of history. As the ways began to part between Judaism and Christianity in the centuries following Jesus' death, Augustine of Hippo presented what would become a dominant framework for understanding the role of Jews within Christian sacred history in ca. 400 CE. Summarizing his views in Contra Faustum, he writes that "[Jews]...still prove useful to the church in a particular condition of servitude, either in bearing witness, or in proving some truth." ${ }^{\prime 47}$ This quote reflects Augustine's Doctrine of Witness, which claims that the Jews' continued presence in history was a byproduct of their didactic and conformational function with regard to Christian faith. ${ }^{48}$ In light of the prevalence

\footnotetext{
${ }^{46}$ Jeffrey K. Olick, introduction to States of Memory: Continuities, Conflicts, and Transformations in National Retrospection, ed. Jeffrey K. Olick (Durham: Duke University Press, 2003), 7.

47 Augustine, Contra Faustum 12.24. See also Sara Lipton, Dark Mirror: The Medieval Origins of Anti-Jewish Iconography (New York: Metropolitan Books), 5.

${ }^{48}$ Paula Fredriksen, Augustine and the Jews: A Christian Defense of Jews and Judaism (New York: Doubleday, 2008), 321-324.
} 
of adversus Iudaeos rhetoric in Christian literature of his age, Augustine's doctrine is notable for the space it creates for Jews alongside Christians as they travel together through time. ${ }^{49}$ That space is necessarily of a lower status, however, as the position assumes the falsity of Jewish claims to a continued covenant with God. $^{50}$

Centuries later, Reformed Theology's move towards scripture as the sole source of doctrine introduced a number of approaches that continued to question the place of Jews and Judaism within Christian sacred history. These new formulations, nevertheless, continued to assume that the covenantal structure that Jesus fulfilled also defined God's relationship with Jews. Moreover, debate remains to this day among those interested in so-called "federal theology" about the place and meaning of the Mosaic covenant between the "covenant of works" and the "covenant of grace" that are supposed to make up "the grand relational framework" that allows for a bond between a holy God and a sinful humanity. ${ }^{51}$ The theological system of Dispensationalism, on the other hand, has yielded an entirely different paradigm for understanding the continued existence of Jews and Judaism within the divine plan of history.

Generally viewed as originating in the writings and preaching of John Nelson Darby (1800-1882), but popularly disseminated in the United States at the beginning of the twentieth century by the Scofield Reference Bible, Dispensationalism lacks a unified creedal statement of belief. ${ }^{52}$ This fact has made it difficult to define, similar to Evangelicalism. In light of this issue, as well as diachronic and synchronic variations in the term's use, Sweetnam has proposed a polythetic definition of Dispensationalism that includes five overlapping fields of stress:

1. A commitment to Evangelical doctrine.

2. A commitment to a literal biblical hermeneutic.

3. A recognition of distinction in manifestations of Divine dealing with mankind, which insists on the uniqueness and importance of both Israel and the Church in the Divine plan.

4. An expectation of the imminent return of Christ in the Rapture.

5. An emphasis on apocalyptic and millennial expectation. ${ }^{53}$

Among these "stresses," number three is most important in the present context. This point indicates Dispensationalism's historiographic hermeneutic, which cites particular biblical passages in order to assert that a series of distinct ages form all of human history. According to this schema, the Jews retain a separate covenant

\footnotetext{
${ }^{49}$ Fredriksen, Augustine, 263-264.

${ }^{50}$ Fredriksen, Augustine, 260-289

${ }^{51}$ R. Michael Allen, Reformed Theology (London: Bloomsbury, 2010), 43.

${ }^{52}$ Arnold D. Ehlert, A Bibliographic History of Dispensationalism (Grand Rapids: Baker Book House, 1965), 5.

${ }^{53}$ Mark S. Sweetnam, "Defining Dispensationalism: A Cultural Studies Perspective," Journal of Religious History 34, no. 2 (2010): 198. doi: 10.1111/j.1467-9809.2010.00862.x.
} 
with God as the heirs of Israel, and their actions in the present and the future will aid in bringing about the second coming of Christ. ${ }^{54}$ The important role that this interpretation gives to Jews in the divine plan for history has helped facilitate a revolution in what Ariel terms "the historical dynamics of Christian-Jewish relationships." 55 Indeed, Sweetnam writes that "Dispensationalism's inherent bias towards philo-semitism has been one of its most visible manifestations and has been at the root of its most influential political interventions."56

Although the term Dispensationalism does not appear in official sources regarding the Creation Museum, the site proposes a periodization of human history that alludes to this theological perspective. As previously mentioned, special placards inform visitors of their passage through distinct phases in time entitled "the $7 \mathrm{Cs}$ " within the Walk Through History. This alliterative schema links the past, present, and future as a continuous and interconnected story. In this way, they reinforce a Young Earth Creationist identity. While unique to the Creation Museum, the $7 \mathrm{Cs}$ nevertheless echo the seven defined ages of Christian eschatology within the theological system of Dispensationalism, especially in the form popularized by the Scofield Reference Bible.

\section{Dispensations}

(According to the Scofield Reference Bible)

\begin{tabular}{|l|l|}
\hline 1. Innocency [Eden to the Fall] & Creation \\
\hline $\begin{array}{l}\text { 2. Conscience [Adam to Noah] } \\
\text { 3. Human Government [Noah to Abra- } \\
\text { ham] }\end{array}$ & Corruption \\
\hline 4. Promise [Abraham to Moses] & Catastrophe \\
\hline 5. Law [Moses to Jesus] & Confusion \\
\hline 6. Grace [The Church Age] & Christ \\
\hline 7. Kingdom [Jesus' Reign] & Cross \\
\hline
\end{tabular}

Both schemas divide history into seven parts. ${ }^{58}$ Additionally, they point specifically to creation, Adam's fall, Noah's flood, the coming of Jesus, and the messiah's future return as epoch defining events. However, the lists diverge in the space given to the "past" from the time of Noah to Jesus. The 7 Cs remain completely silent with regard to the biblical patriarchs or even Moses. Indeed, the entirety of Israelite and Jewish history up to the birth of Jesus receives no explicit attention, whereas this period includes three distinct dispensations in the Scofield

\footnotetext{
${ }^{54}$ Yaakov Ariel, An Unusual Relationship: Evangelical Christians and Jews (New York: New York University Press, 2013), 73-75; Gary Dorrien, "Evangelical Ironies: Theology, Politics, and Israel," in Uneasy Allies: Evangelical and Jewish Relations, eds. Alan Mittleman, Byron Johnson, and Nancy Isserman (Lanham: Lexington Books, 2007), 40.

${ }^{55}$ Ariel, Unusual Relationship, 11.

${ }^{56}$ Sweetnam, "Defining Dispensationalism," 205.

${ }^{57}$ Ehlert, Dispensationalism, 83; Trollinger and Trollinger, Righting America, 45.

${ }^{58}$ It is necessary to note that other sources include different numbers of dispensations.
} 
Reference Bible..$^{59}$ As a result, the 7 Cs effectively erase the memory of Judaism from the totalizing story of the past that the Creation Museum tells.

This erasure goes beyond the $7 \mathrm{Cs}$, as it stands in the background of other representational choices. For instance, the Creation Museum restricts its coverage of Hebrew scripture to Genesis 1-11. This is sufficient text for the museum to cover several well-known biblical stories. However, chapters 11-12 of Genesis are also the moment when the text narrows its story from the descendants of all humans to the particular lineage of Israel. The history through which visitors walk in the Creation Museum's main exhibit, therefore, extends into a mere eleven of the fifty chapters that the Hebrew Bible's first book contains, to say nothing of the remainder of that corpus. From the standpoint of the museum's explicit apologetic goals, focusing on these chapters is pragmatic, since mainstream views of history and science raise the most questions with regard to these stories' historicity. However, the result is that the Creation Museum "pays virtually no attention to ancient Israel..." ${ }^{60}$ If the museum's overall design as a memory place urges visitors to remember a biblical past as their own, then its structure also compels them to collectively forget the Israelite heritage of the Hebrew Bible.

When depictions of Jews and Jewishness do appear in the Creation Museum, their representation continues the narrative of a fossilized people with no contemporary theological meaning. This is clearest in the display devoted to figures from the "Old Testament" in the Biblical Authority room (figure 4).
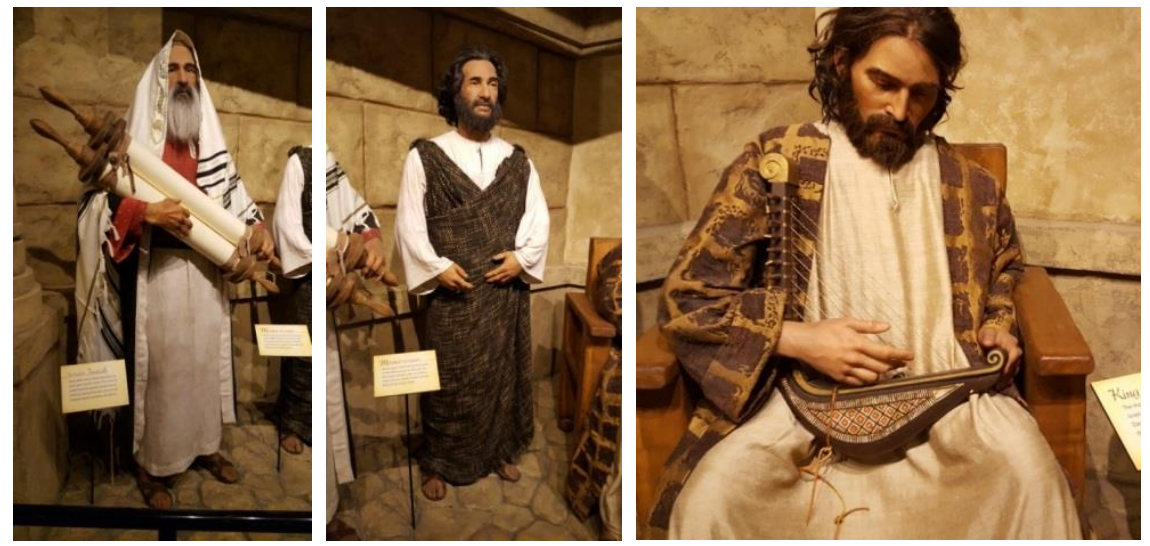

Figure 4. Isaiah, Moses, and David appear side by side in the Biblical Authority Room. The neighboring scene depicts John and Peter peering into Jesus' empty tomb. The displays silently elide the centuries of Israelite and Jewish history that separate these Old and New Testament figures. Photographs by Dustin Nash.

The museum physically portrays only three men in this setting: Isaiah, Moses, and David. The absence or presence of particular visual elements within this tab-

\footnotetext{
${ }^{59}$ Trollinger and Trollinger, Righting America, 46.

${ }^{60}$ Trollinger and Trollinger, Righting America, 48.
} 
leau aligns with the larger narrative regarding Jews and Judaism that the museum implies.

First, the lack of any definable sign of regal identity in the depiction of King David communicates volumes. The figure sits with his head uncrowned and downturned, almost melancholy, playing his lyre. Despite what the accompanying placard states, this is David the psalmist, not David the king. This representation sublimates the biblical memory of a Davidic kingdom, wiping away any notion of a territorial Jewish state as part of messianic expectations. Moreover, with no future Jewish kingdom to rule, the Creation Museum relegates David and his descendants solely to the past, with no continuing theological function in the present. The depiction of David, therefore, correlates directly with the $7 \mathrm{Cs}$ displacement of ancient Israelite history, but stands dissonantly against the notion within Dispensationalism that Israel holds a separate covenant with God.

Just as David has no crown, Moses has no commandments. At the time of my research at the Creation Museum, Moses' arms were empty in the display, as figure 4 illustrates. This does not appear to have always been the case. The companion book Journey Through the Creation Museum shows that at the site's opening, Moses held two stone tablets emblazoned with the text of the Ten Commandments in Hebrew. ${ }^{61}$ Yet, examination of the photograph reveals that the Hebrew text was written in the square Aramaic script, or Ktav Ashuri, including Masoretic vowel points. The square Aramaic script did not come into use for Hebrew until after the Babylonian exile, while the Masoretic scribes' addition of vowel markers dates to the Common Era. ${ }^{62}$ Moses' original tablets in this display, consequently, contained striking anachronisms in script, which did not go unnoticed by the museum's critics. ${ }^{63}$ It appears that the Creation Museum initially removed the tablets in order to address this criticism, which left a noticeable hole that the uncomfortable position of Moses' empty hands made all the more apparent. Tablets have since returned to the display, but the stones that the figure holds are now blank, conveniently avoiding potential epigraphic issues. ${ }^{64}$ Nevertheless, regardless of the varied reasons for the tablets' removal and modification, their current lack of text powerfully communicates the absence of a covenant between the Jewish people and God. The nonexistence of such a relationship defines Moses and the revelatory core of Jewish tradition as artifacts of the past, analogous to the display's representation of David.

Unlike David and Moses, Isaiah stands out for what he does have: a modern tallit gadol. Similar to the changes that Moses has experienced since the muse-

\footnotetext{
61 Journey, 37.

${ }^{62}$ For more on the introduction of the square Aramaic script, see Angel Sáenz-Badillos, A History of the Hebrew Language, trans. John Elwolde (Cambridge: Cambridge University Press, 1993), 113.

${ }^{63}$ Ben Stanhope's critical blog entry that included this subject appears to have elicited multiple online responses from the staff of AiG. However, none of these address the issue of the tablets' anachronistic Hebrew script. See Ben Stanhope, "A Seminary Student Visits the Creation Museum: 27 Million Dollars of Bad Exegesis," Remythologized, last modified August 1, 2014, http://benstanhope.blogspot.com/2013/06/a-seminary-student-visits-creation.html. See also Linville, "Creationist MOTB."

${ }^{64}$ Susan Trollinger, Personal communication, March 24, 2018.
} 
um's opening, the companion book Journey Through the Creation Museum shows that Isaiah originally lacked the Jewish prayer shawl ${ }^{65}$ Indeed, if the presence of pointed square Aramaic script on Moses' tablets is historically inaccurate, then the appearance of this garment upon a late $8^{\text {th }}$ century BCE Judahite is equally so. Such fringed textiles developed as distinct ritual objects no earlier than the Second Temple Period. ${ }^{66}$ Furthermore, although depictions of a few New Testament characters and ark laborers wear kippot, Isaiah and his tallit constitute the clearest portrayal of Jewishness in the entire Walk Through History. Upon first glance this depiction seems far from negative, considering that Isaiah represents an important prophet within both Jewish and Christian tradition. Indeed, Isaiah is graced with such representation at the museum precisely because he is considered a true witness to divine revelation.

However, Isaiah's tallit implies more negative connotations as well. Above all, placing a modern tallit on the ancient prophet situates that ritual garment in the past, making it possible to read its contemporary styling as evidence of a static, or legalistically rigid, Judaism. In addition, the paucity of other figures marked clearly as Jewish within the main exhibit means that the representation implied by Isaiah comes to symbolize Jews and Jewishness as a whole. By association with this figure, then, the museum transports all modern Jews back in time, making them merely the physical remnants of a distant past. Moreover, as Linville notes, the combination of a tallit and scroll in the display evokes a recognizable image of Jewish worship. ${ }^{67}$ This is not the Torah, however. The resulting connection transfers true piety from Moses' "Law" (which is absent in the display) to faith in the messiah that Christian tradition considers the "scroll of Isaiah" to describe. ${ }^{68}$ Consequently, despite the confluence of visual Jewish markers, the representation of Isaiah actually erases any notion of a present or future Jewish tradition, as contemporary symbols are either defined as the echoes of a distant past or appropriated as Christian.

This examination of what the museum selects to forget with regard to Jews and Jewishness, and what it chooses to remember, reveals a rhetorical alignment. The silence and the sound converge to depict Jews as fossils: that is, material remnants of a bygone age with no contemporary theological significance. This depiction appears thoroughly disengaged from a dispensationalist perspective on the role of the Jewish people in history, despite signs of this system's organizational influence on the site. A desire to avoid explicitly aligning the museum with Dispensationalism is understandable in light of AiG's character as a parachurch organization. Such a specific connection might implicate the museum in the ongoing theological rifts between Christian denominations, thereby alienating

\footnotetext{
${ }^{65}$ Journey, 37.

${ }^{66}$ Shaye J. D. Cohen, The Beginnings of Jewishness (Berkeley: University of California Press, 1999), 30-34; Ronald L. Eisenberg, The JPS Guide to Jewish Traditions (Philadelphia: The Jewish Publication Society, 2008), 380.

${ }^{67}$ Linville, "Creationist MOTB."

${ }^{68}$ Placard Text, "The Prophet Isaiah," Biblical Authority, Creation Museum, Petersburg, KY; Linville, "Creationist MOTB."
} 
potential visitors. But if a separate Jewish covenant is written out of the story that the museum tells, what about other theological frameworks such as the Doctrine of Witness? Why is it that Jews are left as insignificant material remnants of the past at a site that unambiguously asserts the designed, created, and purposeful nature of all space and time? Examination of other portions of the site indicates that the surprising answer to this question lies in the very things that the Creation $\mathrm{Mu}$ seum most wants its visitors to remember as part of the Christian past: dinosaurs.

\section{Remembering Dinosaurs as Part of the Christian Past}

Mainline American protestant denominations have theologically engaged with a variety of models to reconcile the idea of an ancient Earth with the text of Genesis 1 since the late $19^{\text {th }}$ century. ${ }^{69}$ However, the fossil record and its traditional interpretation remain challenging for any notion of the Bible's "real historical character," which constitutes a central tenant of Young Earth Creationism. ${ }^{70}$ The core of this problem lies in the Bible's apparent silence concerning dinosaurs and these creatures' nature as material, paleontological facts. Nevertheless, the Creation Museum website unambiguously declares that "Creationists love dinosaurs and dinosaur bones because they confirm the truth of the Bible."71 The evidence of this love is blatantly obvious at the museum, with representations of dinosaurs bombarding visitors from the moment one enters the parking lot (figure 5).

\footnotetext{
${ }^{69}$ Numbers, Creationists, 7.

${ }^{70}$ George M. Marsden, Understanding Fundamentalism and Evangelicalism (Grand Rapids: William B. Eerdmans Publishing Company, 1991), 4-5.

71 “Dinosaurs and Dragons," accessed June 1, 2018, https://creationmuseum.org/dinosaurs-dragons/.
} 

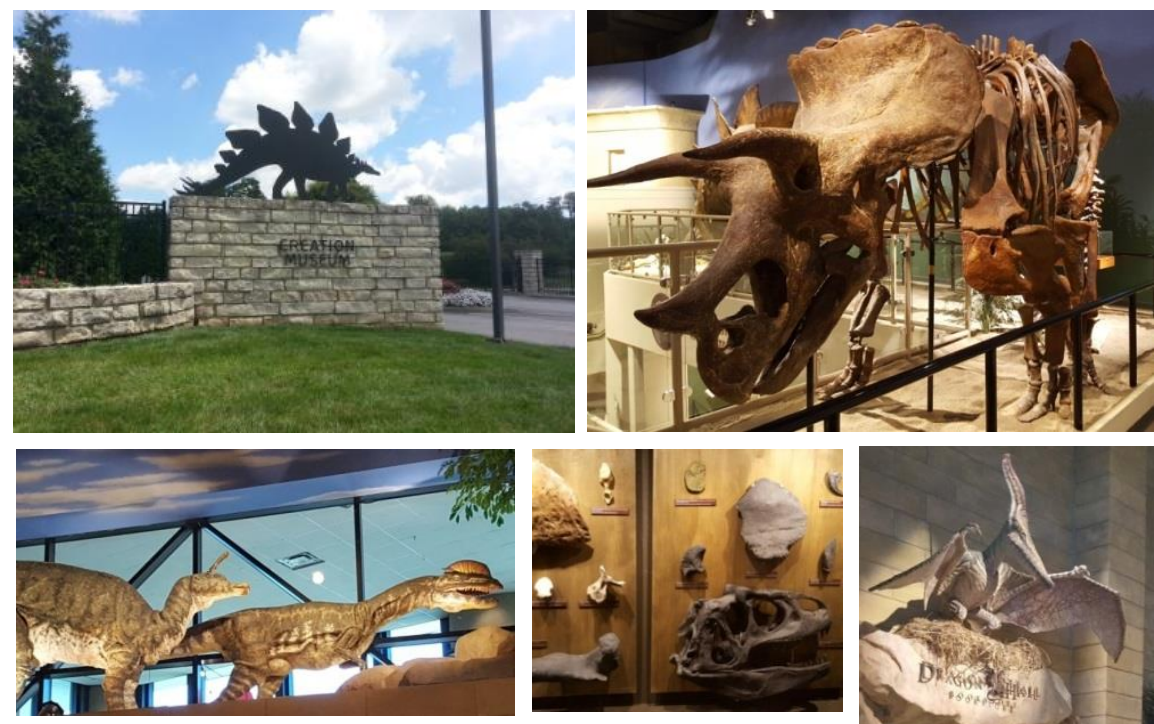

Figure 5. Examples of dinosaurs and other ancient reptiles found at the Creation Museum. In the upper left hand image, the silhouette of a stegosaurus greets visitors at the main gate. The recreation of a fully articulat-

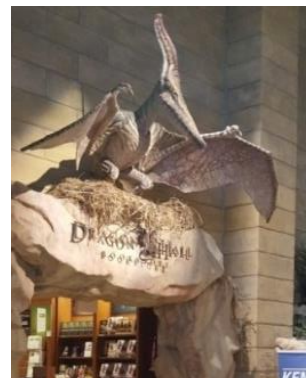
ed triceratops skeleton stands in Buddy Davis' Dino Den in the upper right hand image. In the bottom row, what appears to be a tsintaosaurus and dilophosaurus stand together in the Main Hall, where displays of dinosaur fossils such as the middle image also appear. In the lower right hand photo, a pteranodon perches above the entry to the "Dragon Hall Bookstore." Photographs by Dustin Nash.

Although official AiG statements and literature connect this emphasis on dinosaurs to a host of practical and apologetic concerns, analysis shows that the creatures serve a specific function within the memory that the site constructs by bearing witness to the truth of Christian scripture. Yet, with a dispensational perspective set aside, the museum's emphatic remembrance of dinosaurs with this purpose disinherits the Jewish people's claim to this older, albeit problematic, function in Christian history.

Within conventional scientific thought, dinosaurs represent an ancient group of terrestrial vertebrates, the non-avian examples of which went extinct roughly sixty five million years ago. However, as a symbol and cultural artifact, dinosaurs are alive and well. The idea that newly discovered fossils from Western Europe were the remains of extinct reptilian creatures that lived prior to the appearance of humans first arose in the $19^{\text {th }}$ century. ${ }^{72}$ Since that time, although interest in these animals has waxed and waned to the rhythm of popular culture and scientific discovery, dinosaurs have nevertheless occupied a role that Mitchell defines as "the

\footnotetext{
${ }^{72}$ José Luis Sanz, Starring T. Rex! Dinosaur Mythology and Popular Culture (Indianapolis: Indiana University Press, 2002), 2.
} 
totem animal of modernity." ${ }^{73}$ By this, Mitchell means that dinosaurs arose as symbolic animals first in the modern era, that their very existence epitomizes modern notions of time as both deep and progressive, and that they play important ritual roles within the structures that erect and maintain modern identities. $^{74}$ Dinosaurs are, nevertheless, more than symbolic. As Noble notes in his study of these creatures' popular and scientific representation, they are also "natural beings."75 Dinosaurs are, thus, monstrous and yet not monsters; they are imagined yet also real. This liminal identity has made dinosaurs "amenable to both scientific investigation and public wondering." "76 They were, as a result, the ideal object to embody the civilizing goals of modern public museums at the end of the nineteenth and the beginning of the twentieth centuries. ${ }^{77}$ The effect of this marriage between dinosaurs and public museums is that these creatures have become emblematic of science in general and evolution in particular. ${ }^{78}$

The popular association of dinosaurs with evolution is not lost on those that espouse a Young Earth Creationist identity. For instance, at the beginning of his expansive, Creation-oriented survey of dinosaurs and the field of paleontology, Clarey laments that contemporary scientists "actively twist the truth to convince people that dinosaurs are 'proof' of evolution." "79 Ham reiterates this idea in his booklet What Really Happened to the Dinosaurs?, in which he writes that these animals are used "more than almost anything else to indoctrinate children and adults in the idea of millions of years of earth history." ${ }^{80}$ Behind each of these statements lies a key assumption of AiG and the Creation Museum: the notion that "science actually confirms biblical history..." 81 Thus, both Clarey and Ham would agree that their issue lies not in science, but rather in what they perceive as "bad science." Young Earth Creationism as more scientific than the practices of mainstream researchers. The hyper-prevalence of dinosaurs at the site supports this goal, due to these animals' symbolic nature as especially affective embodiments of science.

\footnotetext{
${ }^{73}$ On the rise and fall of public interest in dinosaurs at the end of the twentieth century, see Stephen Jay Gould, "Dinomania," in Dinosaur in a Haystack: Reflections on Natural History (New York: Harmony Books, 1995), 221-224; W. J. T. Mitchell, The Last Dinosaur Book (Chicago: The University of Chicago Press, 1998), 77. Writing in 1998, Mitchell suggests that the dinosaur's function in this role may actually be in irreversible decline as a byproduct of cultural over-determination. Mitchell, Last Dinosaur Book, 85.

${ }^{74}$ Mitchell, Last Dinosaur Book, 77.

${ }^{75}$ Brian Noble, Articulating Dinosaurs: A Political Anthropology (Toronto: University of Toronto Press, 2016), 18.

${ }^{76}$ Noble, Articulating Dinosaurs, 13.

${ }^{77}$ Tony Bennett, The Birth of the Museum: History, Theory, Politics (London: Routledge, 1995), 47.

${ }^{78}$ Mitchell, Last Dinosaur Book, 82, 137; Larry A. Witham, Where Darwin Meets the Bible: Creationists and Evolutionists in America (Oxford: Oxford University Press, 2002), 182.

${ }^{79}$ Tim Clarey, Dinosaurs: Marvels of God's Design (Green Forest, AR: Master Books, 2015), 12.

${ }^{80}$ Ken Ham, What Really Happened to the Dinosaurs? (Hebron, KY: Answers in Genesis, 2007), 1.

81 "The Creation Museum: Main Theme and Vision Statement," Creation Museum Media Kit, accessed May 5, 2016. http://creationmuseum .org/press/.

${ }^{82}$ On the idea that evolution constitutes "bad science," see Jason Lisle, "Evolution: The AntiScience," last modified February 13, 2008,

https://answersingenesis.org/theory-of-evolution/evolution-the-anti-science/.
} 
Moreover, once viewed from this perspective, the didactic function of dinosaurs that originally served the theory of evolution can be applied to a creation model of earth's origins. Dinosaurs become "missionary lizards" as a result, aiding in the spread of what Davis describes as the "Young-Earth Creationist gospel.",83

An emphasis on countering the evolutionist use of dinosaurs constitutes AiG and the Creation Museum's explicit discourse surrounding the animals' frequent appearance in official writings and at the site. However, the structure and representation of dinosaurs within the Creation Museum indicates that they are also being portrayed as uniquely significant witnesses to the truth of the biblical account, both in body and in vision. In this way, the memory of dinosaurs provides legitimacy to the Young Earth Creationist past that the museum constructs. Mobilizing dinosaurs in this way, moreover, parallels Augustine of Hippo's apologetic use of Jews and Jewish tradition in his response to Faustus the Manichaean's critique of Catholic Christianity in the early fifth century. ${ }^{84}$ Rather than seeing the use of Jewish scriptures as evidence against the morality or truth of the church, as Faustus claimed, Augustine argued that Jewish scripture and the contemporary social position of the Jewish people bore positive witness to the truth of Christianity and the inherent connection between the Old and New Testaments. ${ }^{85}$ In an analogous fashion, the Creation Museum remembers the very things most commonly cited as evidence against a Young Earth interpretation of Earth's history (i.e. dinosaurs and fossils) as witness to its accuracy.

The depiction of dinosaurs as serving this function is especially visible within and around the museum's main exhibit. Thus, visitors approaching the entrance to the Walk Through History do not see recreated scenes of episodes from Genesis, but rather dinosaurs (figure 6).

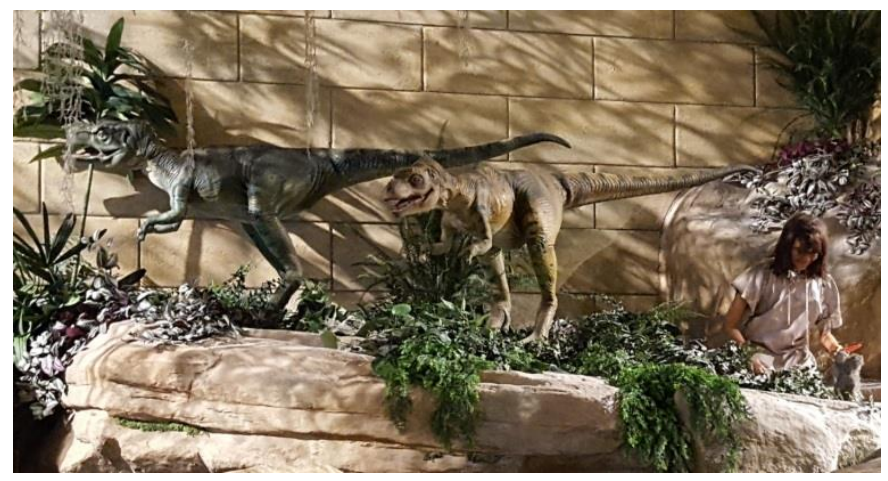

Figure 6. Two young tyrannosaurs stand next to a human child in a scene outside the entry to the main exhibit. Photograph by Dustin Nash.

\footnotetext{
${ }^{83}$ Buddy Davis, "How Can We Use Dinosaurs to Spread the Creation Gospel Message?" last modified February 14, 2008, https://answersingenesis.org/gospel/evangelism/how-can-we-use-dinosaursto-spread-the-creation-gospel-message/. See also Barone, "New Pulpit," 80.

${ }^{84}$ Fredriksen, Augustine, 214.

${ }^{85}$ Fredriksen, Augustine, 235-259.
} 
Two young animatronic tyrannosaurs stand beside children playing happily in an idyllic garden scene. Towering over the adjoining wall, an unspecified sauropod sweeps its long neck over visitors as it eats vegetation (figure 7).

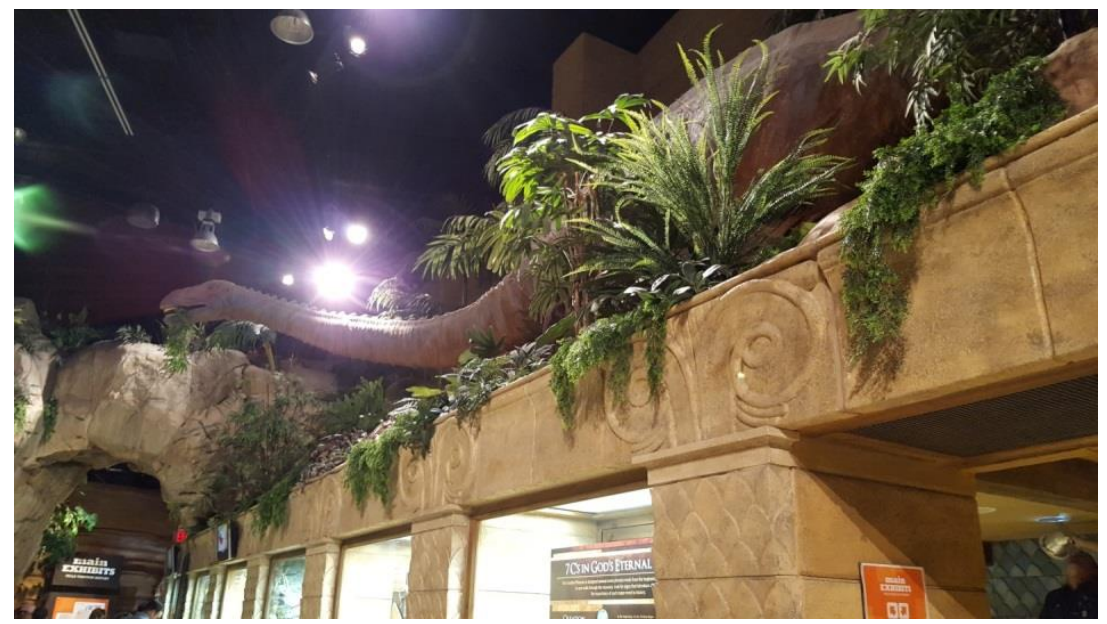

Figure 7. A sauropod of unknown species eats vegetation across from a display of tyrannosaurs and children in the entryway to the main exhibit. Note that the dinosaur stands atop a series of Iron Age proto-aeolic capitals. Photograph by Dustin Nash.

The companion book to the Creation Museum states that the function of this introductory scene is "to challenge people right from the start of their museum experience about the coexistence of dinosaurs and people." ${ }^{\prime \prime 6}$ The juxtaposition of humans and dinosaurs in the display, however, has deeper implications. The AiG website, official publications, and placards within the Creation Museum consistently claim that God created dinosaurs along with other land animals on day six of creation, prior to Adam and Eve. ${ }^{87}$ Dinosaurs, accessible in the present through their material remains, are thus made unbiased contemporary observers of the human past. And in the museum's perspective, the human past equates with the biblical narrative. Therefore, even before entering the first room, displays invite the visitor to view dinosaurs as the foremost non-Christian witnesses to biblical truth and to remember them as part of humanity's past.

Once inside the main exhibit, depictions of fossils construct an inclusio that brackets the intervening rooms at their beginning and end. This emphasis on material remains defines the visual rhetoric of the first room, labeled Dig Site. A life-size display of two paleontologists working together to expose the skeleton of what appears to be a dromaeosaurid dinosaur, perhaps a deinonychus or utahrap-

\footnotetext{
${ }^{86}$ Journey, 16.

${ }^{87}$ Ham, Dinosaurs, 8; Bodie Hodge, "Why Don't We Find Human \& Dinosaur Fossils Together?" last modified November 1, 2007, https://answersingenesis.org/dinosaurs/humans/why-dont-we-findhuman-dinosaur-fossils-together/. For more on the broader Young Earth Creationist view of dinosaur origins, see Clarey, Dinosaurs, 11-12; Guide to Dinosaurs (Eugene: Harvest House Publishers, 2015), 14; Brian Thomas, Dinosaurs and the Bible (Eugene: Harvest House Publishers, 2013), 9-13.
} 
tor, stands at its center. A Bible rests at the side of one excavator, creating a physical association between the bones and Christian scripture. However, with the exception of this one book, there is no other reference to the Bible within the room. Instead, the fossilized remains of the ferocious theropod dominate the space (figure 8).

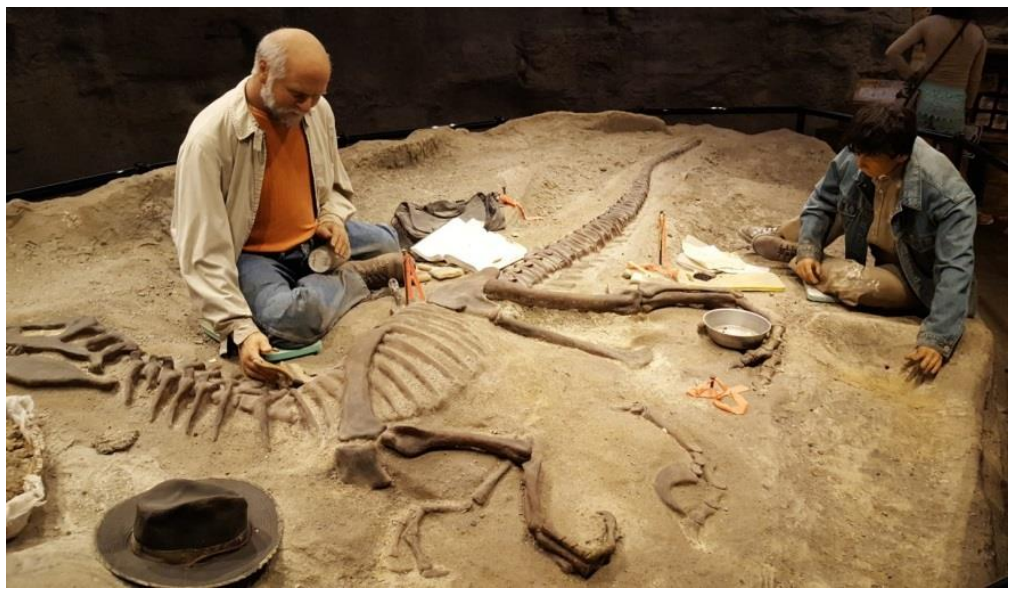

Figure 8. Two paleontologists, one a Creationist and the other an Evolutionist, excavate a fossil at the center of the Dig Site room. Photograph by Dustin Nash.

At the end of the Walk Through History, visitors encounter the well-preserved skeleton of a full-grown allosaurus, which the museum names Ebenezer (figure 9). Although a different species, there are links between this dinosaur and that of the Dig Site room.

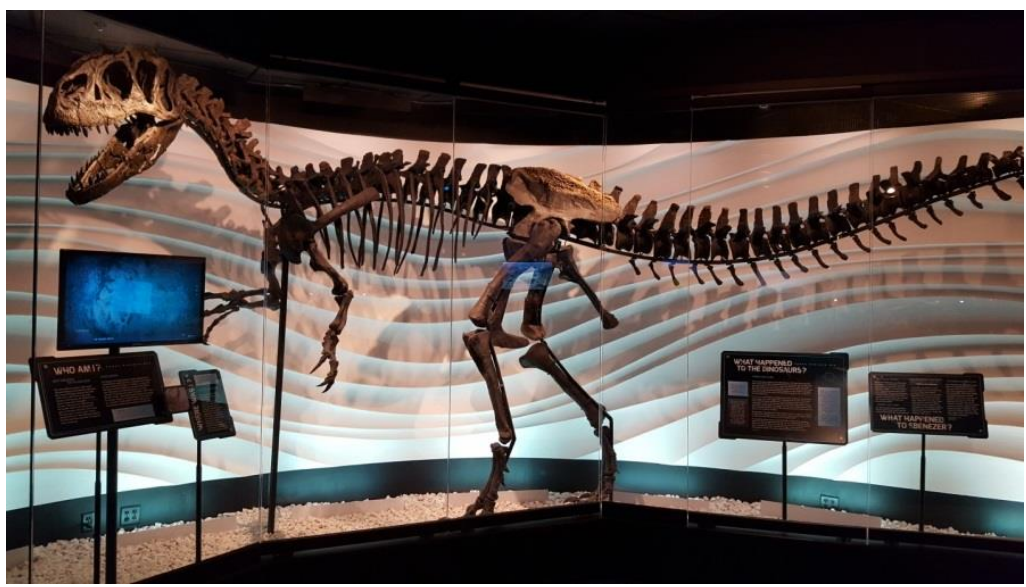

Figure 9. Ebenezer the Allosaurus. Photograph by Dustin Nash. 
These are the only two representations of full dinosaur skeletons within the Main Exhibit. As fossils, these objects point to the remnants of those creatures that remain accessible to us today. However, while the place of the dromaeosaur within biblical history remains superficially undetermined, the allosaurus' is patently clear. Its display blends with that of the Flood Geology room, which asserts that a past cataclysmic global flood provides the best explanation for the geological and paleontological record. How we, today, came to look upon the skeleton of this deceased allosaurus is therefore obvious within the memory of the past that the museum constructs. As the placard before the dinosaur states, it died alongside most other dinosaurs and became fossilized as a result of Noah's flood: "Ebenezer is only one example of what occurred on a global scale to billions of creatures. Except for those on Noah's Ark, all of the dinosaurs, other land creatures, birds, and humans died in the global catastrophe." 88 This knowledge redefines the meaning of the skeleton in the first room, making both animals' deaths witnesses in the present to the accuracy of the Bible's description of the past.

Portrayals of dinosaurs within the Walk Through History build on the rhetorical frame that the skeletal remains create by focusing on the creatures as living witnesses to the biblical narrative as well. In moving from the Dig Site room to the adjoining Starting Points room, the "word" of the dinosaur's bones becomes "flesh" in a life-size depiction of the animal in all its terrifying glory (figure 10).

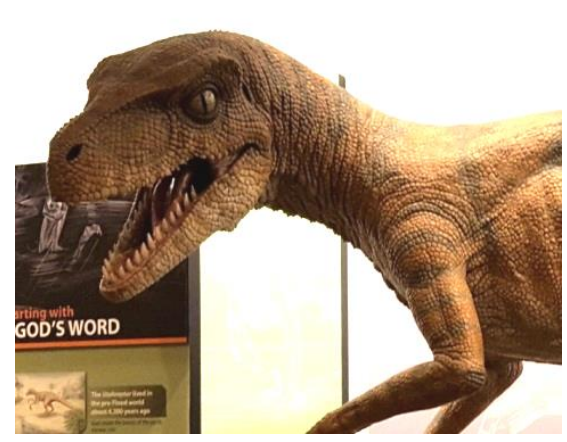

Figure 10. The menacing dinosaur in the image above greets patrons as they enter the Starting Points room. The associated placards, which describe conflicting Creationist and Evolutionist interpretations of when the animal died, clearly associate it with the skeleton in the preceding Dig Site room. Photograph by Dustin Nash.

Related signage uses the dinosaur as a symbol for judging between "Man's Word" and "God's Word." 89 In this comparison, the creature's life and death represent a witness to the truth of the Bible.

Moving deeper into the main exhibit, dinosaurs also feature prominently within the video shown in the Six Days Theater. As Adam and Eve look upon the

\footnotetext{
${ }^{88}$ Placard Text, "What Happened to Ebenezer?," Facing the Allosaurus, Creation Museum, Petersburg, KY.

${ }^{89}$ Placard Text, "Starting with God's Word, Starting with Man's Word," Starting Points, Creation Museum, Petersburg, KY.
} 
Garden of Eden in the film's final moments, the necks of what appear to be brachiosauruses become visible above the trees. The creatures' existence within paradise makes them literal eye witnesses to biblical history in a way that repeats in subsequent rooms. Thus, in the Garden of Eden room, a hadrosaur and ankylosaur of undetermined species look on as Adam names animals, in accordance with Genesis 2:19-20. A large therapod dinosaur eats leaves from a tree deeper within the room as well, directly above the human couple (figure 11).
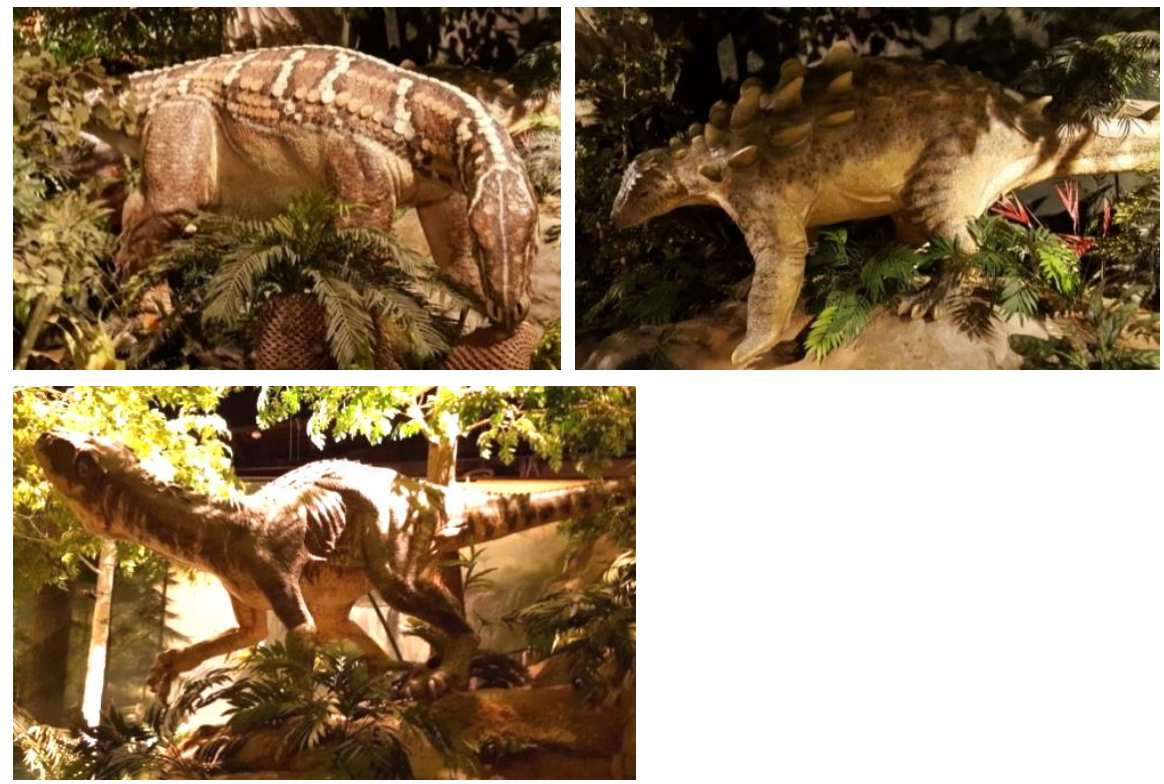

Figure 11. Dinosaurs grazing in the Creation-Garden of Eden room. Photographs by Dustin Nash

The following Cave of Sorrows room argues that Adam's sin of disobedience shattered the utopian world of human and dinosaur cohabitation that the CreationGarden of Eden room displays. In its place, the visitor confronts a graphic scene of dinosaur-on-dinosaur violence (figure 12).

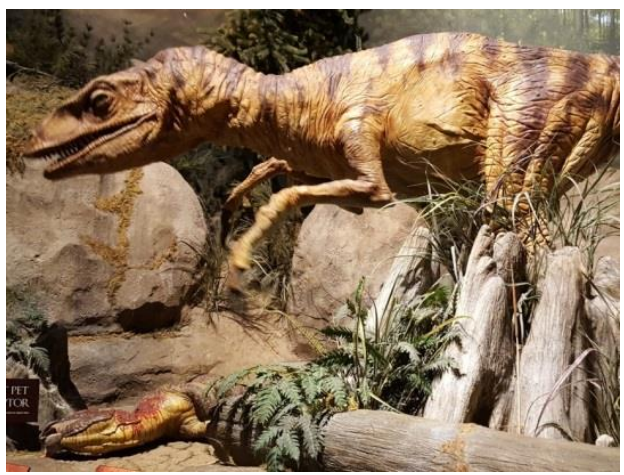

Figure 12. The animatronic display that appears in the image above graphically illustrates the development of dinosaur predation following Adam's sin. Photograph by Dustin Nash. 
According to the multiple signs associated with this display, Adam's sin released death and predation into the world. Therefore, this creature's clear predator identity links and confirms the relationship between biblical history and the present world order, in which certain animals are needed to remove the weak and the diseased "to keep the fallen world functioning despite sin." 90 Finally, in the Voyage of the Ark room, dioramas of life inside that vessel during the flood show juvenile hadrosaurs in stalls alongside other animals. An animatronic Noah explains that, although he knows them as dragons, dinosaurs were brought aboard the ark two-by-two according to their 'kind,' similar to all other land animals. ${ }^{91}$ As a result, these creatures were also living witnesses to this defining event of the biblical past. Indeed, the museum contends that legends of dragons and other mythological beasts from around the globe constitute faded human memories of interactions with these animals' postdiluvian ancestors, before their eventual extinction.

Therefore, whereas visitors encounter silence when looking for Jews at the Creation Museum, they confront a thundering roar with regard to dinosaurs. There would be no reason to read this correlation as causative, however, if not for the function that the museum's displays rhetorically define for the ancient reptiles within the Young Earth memory of the past that the site constructs. The facility's insistent portrayal of dinosaurs as witnesses to the truth and historical accuracy of Christian scripture has left no functional space for Jews and Jewishness to reside within an all-encompassing narrative of time.

\section{Conclusion}

The preceding analysis indicates that a series of discrete choices made in constructing the Creation Museum's Young Earth memory of the biblical past has produced an unlikely, and perhaps unintentional, rhetorical connection. To put it simply, Jews and dinosaurs have traded places. In order to avoid staking a position within a contentious theological debate, the museum presents a narrative that removes Jews from an otherwise dispensational vision of history. At the same time, the site's overriding discursive interest in appropriating dinosaurs as symbols of scientific authority has led to an argument that asserts the creatures' function as witnesses to biblical truth: a dinosaurian Doctrine of Witness, if you will. There is, consequently, no space left within this purposeful narrative of time for Jews, leaving them as an inconvenient relic whose place in space and time is undetermined. This conclusion begs the question of how such a public memory

\footnotetext{
${ }^{90}$ Placard Text, "Carnivores," Corruption-Cave of Sorrows, Creation Museum, Petersburg, KY.

${ }^{91}$ Animal 'kinds' are an important concept for AiG and the Creation Museum. According to Genesis 1, God created every plant and animal "according to its kind" (למינו; lěmînô). This terminology repeats in Genesis 6:20-22 in description of the "kinds" of animals that Noah is instructed to take aboard the Ark. Creation scientists define the practice of categorizing fossilized and living creatures into created kinds as "baraminology," from the Hebrew terms for "to create" (ברא; bāra) and "kind" (מין; $m$ în). Bodie Hodge and Georgia Purdom, "What are 'Kinds' in Genesis?," last modified April 16, 2013, https://answersingenesis.org/creation-science/baraminology/what-are-kinds-in-genesis/.
} 
may affect its audiences' perceptions of, or relations with, Jews in the future. Any answer proposed at this time, however, would be speculative at best. Nevertheless, I would argue that alarm should be raised whenever we observe Jews being collectively forgotten. 